\title{
Tectonomagmatic considerations about the Cimmerian metamorphism and magmatism in Bulgaria
}

\section{Тектономагматични особености на кимерския метаморфизъм и магматизъм в България}

\section{Ivan Zagorchev \\ Иван Загорчев}

Bulgarian Academy of Sciences, 1000 Sofia

\begin{abstract}
Problems of the Cimmerian igneous activity are briefly discussed at the background of the plate tectonics of the Balkan Peninsula. We mostly comment on the relations of the tectonometamorphic evolution of the Bulgarian territory with the Vardar Ocean and its subduction beneath the European continent. A number of problems still remain open especially in regard to the Jurassic evolution of the Rhodope massif.
\end{abstract}

Keywords: Alpine magmatism, geodynamic relations, Jurassic Rhodopes.

\section{Увод}

Проблематиката на херцинския и алпийския магматизъм на Балканите е тясно свързана с геодинамиката (Dabovski et al., 1991, 2002) на тези най-важни за региона тектонски ери. С настоящето съобщение се прави опит за интерпретация на тази тематика в светлината на многобройни изотопни геохроноложки резултати от последните двадесет години. Особено внимание се отделя на отзвука от отварянето на Вардарския океан и неговата последваща субдукция под Европейския континент в консолидираната континентална кора на последния.

\section{Херцинското наследство}

Към края на Палеозойската ера в земите на Балканския полуостров протича консолидация на Земната кора, като в рамките на Пангея ясно се индивидуализират Мизийската платформа, Херцинидите (палеозойските Балканиди и Динариди) и една зона на консолидиран високометаморфен фундамент (с преобладаващо гранитоидно-гнайсова кора), наричана Тракийски масив или Тракийски терен. Всяка от тези три тектонски области се характеризира с различно поведение и история по време на алпийското развитие. Тук ще обърнем внимание само върху формирането на херцинската гранитоидногнайсова континентална кора от Тракийския масив/терен, като в обхвата на това понятие включваме всички части на полуострова, обозначавани като „високометаморфен фундамент“: целия обхват на Сръбско-Македонския масив (CMM), Родопския масив, „кристалинните блокове“ от Средногорието (Централносредногорския - ЦСГб, Ихтиманския, Сакарския, фундамента на Странджа), както и Пелагонския масив. В тази кора различаваме дохерцински реликти (метаморфни комплекси амфиболитов фациес), които включват както базични и ултрабазични тела и пластове, така и гранитоиди, всички с доказана кадомска възраст (например, метабазитите от Централните и Източните Родопи, много метабазити и гранитогнайси от различни части на СММ, Бобевишките гранити в ЦСГб Carrigan et al., 2006). Вероятно Бобевишките гранити и други подобни от СММ и други части на Тракийския терен са разделяли две големи епохи на метаморфизъм (докадомски и кадомски), а началото на херцинския метаморфизъм трябва да се отнесе към 360-340 Ма (по различни данни). Пак към времето 340 Ма трябва да отне- 
сем, по $\mathrm{Rb}-\mathrm{Sr}$ данни, началото на генериране и внедряване на магмите на базичните интрузиви (Чавдар, Ломашко дере, базичните дайки южно от с. Пролом) като прекурсори и отчасти, едновременно образувани с първия гранитоиден комплекс (Смиловенски и Хисарски плутон) с неговите особености на смесен, мантийно-коров произход. Както тези плутони, така и тези от втория и левкогранитите от третия комплекс, показват по цирконите датиране в интервала 310-300 Ма, като достигат при Стрелчанския плутон дори около $285 \mathrm{Ma}$ (по $\mathrm{Rb}-\mathrm{Sr}$ данни - датировки за първия комплекс $2340 \mathrm{Ma}$, за Стрелчански плутон триаска възраст от $245 \mathrm{Ma}$ ). Нарочно цитирам тези данни, защото те съвпадат с възрастта на преобладаващите гнайс-гранити от Родопския масив, при превес на интервала 310-295 Ма. Основната разлика е липсата на наложен алпийски метаморфизъм в ЦСГб, докато в Родопите повсеместното образуване на гранитогнайси протича при сложно преплитане на херцински метаморфни и магмени процеси и наложени аналогични процеси с алпийска възраст.

\section{Триаски и юрски магмени събития}

Ранномезозойските (кимерските) магмени събития са тясно свързани със създаването и развитието на Вардарския океан. Това са поредица от революционни явления на разпадане на Пангея, намерили значително отражение и в континенталната кора от източната част на Балканите. Пряка връзка с океана и неговия магматизъм, предимно базичен и със срединноокеански или дъгов произход, имат на българска територия Мандришко-Макринската единица (Източен Циркумродопски пояс) и сложните единици от Странджа (вж. Dabovski et al., 2002; Bonev, 2020). Поради силно разкъсания и алохтонен характер на тези единици, магматизмът, предимно с островно-дъгов характер, остава недостатъчно изяснен; получените възрасти (Bonev, 2020) обхващат един значителен интервал от Средната Юра до Долна Креда (от 170 до 140 Ма, т.е. около 30 млн. год.). Както в тези единици, така и във Вардарския океан s.s. почти не са установени триаски възрасти, макар че съществуват доста обосновани предположения и индикации за магмени събития и през Триаския период.

Отражението на тези събития в континента на север отдавна се предполага от редица автори, като се започне от Д. Яранов. Далечен отзвук е свързаният вероятно с началното отваряне на Вардарския океан ранно- и среднотриаски базичен вулканизъм в Мизийската платформа (вж. Dabovski et al., 1991, 2002; Zagorchev et al., 2009). Дайков триаски магматизъм с базичен до сред- нокисел състав е регистриран и в някои части на Маришката зона. Трябва да се подчертае, че за разлика от Източния Циркумродопски пояс, който е непосредствена окрайнина на Вардарския океан, в отдалечените части на континента липсва юрски магматизъм, така че кората е била силно консолидирана, въпреки образуването на късноюрско-раннокредния Ниш-Троянски (Перимизийски) флишки трог на ръба между платформата/Балканидите и Тракийския масив. Образуването на този трог и неговото затваряне към края на Ранната Креда не са се отразили чрез магмена активизация на дълбоките корови и мантийни нива, а са имали епидермално тектонско влияние (Zagorchev, Tchoumatchenco, 2017).

Може би най-интригуващият проблем в интерпретацията на кимерските събития засяга поведението на сравнително консолидирания Тракийски масив. Преди всичко, поради образуването на Вардарския океан, от масива се отделя Пелагонският масив, който претьрпява значителна преработка по време на тектонската еволюция на океана. Такава преработка наблюдаваме и по западната периферия на СММ. От друга страна, вероятно още през Триаса е започнало и отделянето от Тракийския масив на ЦСГб, за което съдим от триаските дайки в Маришката зона и от наличието на Панагюрската и Старозагорската горнокредни ивици, които прекъсват в Маришката зона. Дали това прекъсване е било първично (кимерско), или ЦСГб е бил изолиран от Родопския масив едва през Късната Креда с формирането на Средногорската зона, бихме могли да изясним само със сондиране.

Тук неизбежно стигаме и до проблема дали триаският гранитен магматизъм от СММ и пермско-триаският такъв от ЦСГб са също свързани с процесите на рифтинг в Европа, или са продължение на описания по-горе херцински магматизъм като негова остатьчна, предимно левкогранитна фаза. Като се вземе предвид наличието на такъв преход във времето, регистриран чрез гранитпорфировия магматизъм от Сливенско, мнението на автора клони по-скоро в полза на втората хипотеза.

Още един интересен проблем засяга доста широкото развитие на юрски метаморфизъм в Родопския масив (преглед у Zagorchev et al., 2018). В отделни случаи юрският метаморфизъм е наложен като присъствие на отделни цирконови зърна (или обособени зони в зонални зърна) в палеозойски гнайс-гранити. В части от Западните и Централните Родопи обаче юрските възрасти от интервала 160 (165) до 150 Ма се регистрират в целия обхват на Бойковската, Бачковската и Луковишката свита, както в левкогранитогнайсовите, така и в метаседиментните скали, а в 
Западните Родопи и в амфиболити (метагаброиди). Тези данни за възрастта на цирконите там намират обяснение с няколко много различни хипотези: /1/ Разглеждайки въпросните скални последователности в контекста на регионалните корелации на балканските метаморфни комплекси, трите свити се корелират с подобни скали от Пиринско-Пангеонската единица, където в тях са установени къснопалеозойски (280-300 Мa) възрасти. Левкогранитогнайсите при това се приемат за метааркози, претьрпели на места дори анатексис и образуване на гранитоидни тела и дайки (вероятно, като Добралъшките гранитоиди, левкогранитните и аплитоидни мобилизати при Бачково, и т.н.). Вземат се предвид и единичните юрски цирконови определения сред „море“ от палеозойски възрасти, както херцински, така и по-стари, в другите части на Родопите като доказателство за повсеместно развитие в Родопския масив на едно юрско наложено метаморфно явление. Слабост на тази гледна точка е наличието, макар и единични, на юрски датировки и в доста масивни и практически почти неметаморфозирани габроиди от Западните Родопи. /2/ Една друга хипотеза (Froitzheim et al., 2014), продължаваща с изотопни доказателства стара идея на Д. Динтер, предполага грандиозна, полегата до хоризонтална, субдукция на „вардарски“ динаридни магмени и метаседиментни скали под родопските s.s. метаморфити на Централните Родопи, при хоризонтално придвижване от порядъка на $500 \mathrm{~km}$. Тази екстремно-алохтонна хипотеза категорично отхвърля Родопския масив като балканиден елемент и го отнася към Вътрешните Хелениди. Метаморфните скали и изградените от тях ,литотектонски единици“ се считат за изцяло юрски, т.е. цирконовите дати се приемат за възрасти на протолитите. В тази светлина се отхвърля и всяка възможна корелация на метаморфните свити в пределите на целия Родопски масив. Друга слабост е несъобразяването с действителното положение на тази скали (Бачковско-Асеновградски комплекс, s. Zagorchev, 2008). /3/ Положението на Бачковско-Асеновградския комплекс върху Рупчоския в Централните Родопи и данните за негова кадомска възраст (вж. Zagorchev, 2019) предполагат както принадлежност към Балканидите, така и образуване на Бачковските левкогранитогнайси и тяхното юрско преобразуване по пътя на анатексис. От друга страна, в последно време се разисква възможността протолитите на този комплекс да са с пермско-триаска възраст, по аналогия със Сакарския триас, сьщо започващ с дебели метапсамити, преминаващи чрез тънка метакарбонатно-метапелитна алтернация в дебели метакарбонати. Дори ако такава алтернатива бъде доказана, тя не изключва хипотезата за юрски възрасти, получени чрез интензивен синтектонски метаморфизъм, а би обяснила наличието на метабазитите с аналогична възраст с евентуално проникване на базични юрски магми. И в двата случая е логично да приемем, че в среднои късноюрско време херцински консолидираната кора на Родопския масив е претьрпяла в дълбочинна обстановка ново удебеляване и значителни тектонотермални въздействия и изменения, достигащи до анатексис.

\section{Заключение}

Въпреки значителния напредък на петроложките и геохроноложките изследвания в България, ред проблеми на кимерската геодинамика остават открити. Това засяга както мезозойския магматизъм на Мизийската платформа, така и „конфликтното пространство“ между нея и оформеното „горещо ядро“ на Родопския масив.

\section{Литература \\ References}

Bonev, N. 2020. Geology of the Eastern Circum-Rhodope Belt. Sofia, St. Kliment Ohridski Publ. House, 147 p. (in Bulgarian).

Carrigan, C. W., S. B. Mukasa, I. Haydoutov, K. Kolcheva. 2006. Neoproterozoic magmatism and Carboniferous highgrade metamorphism in the Sredna Gora Zone, Bulgaria: An extension of the Gondwana-derived Avalonian-Cadomian belt? - Precambrian Res., 147, 3, 404-416.

Dabovski, C., I. Boyanov, K. Khrischev, T. Nikolov, I. Sapounov, Y. Yanev, I. Zagorchev. 2002. Structure and Alpine evolution of Bulgaria. - Geologica Balc., 32, 2-4, 9-15.

Dabovski, C., A. Harkovska, B. Kamenov, B. Mavrudchiev, G. Stanisheva-Vassileva, Y. Yanev. 1991. A geodynamic model of the Alpine magmatism in Bulgaria. - Geologica Balc., 21, 4, 3-15.

Froitzheim, N., S. Jahn-Awe, D. Frei, A. N. Wainwright, R. Maas, N. Georgiev, T. Nagel, J. J. Pleuger. 2014. Age and composition of meta-ophiolite from the Rhodope Middle Allochthon (Satovcha, Bulgaria): A test for the maximumallochthony hypothesis of the Hellenides. - Tectonics, 33, 1477-1500; https://doi.org/10.1002/2014TC003526.

Zagorchev, I. 2008. Amphibolite-facies metamorphic complexes in Bulgaria and Precambrian geodynamics: controversies and "state of the art". - Geologica Balc., 37, 1-2; 33-46.

Zagorchev, I. 2019. Comments on the use of Sr isotopes, $\delta^{18} \mathrm{O}$ and $\delta^{13} \mathrm{C}$ for age determinations of the protolith(s) of the Rhodopian marble formation(s). - Rev. Bulg. Geol. Soc., $80,1,35-39$.

Zagorchev, I. 2021. Geology of the Balkan Peninsula. - In: Alderton, D., S. A. Elias (Eds.). Encyclopedia of Geology. 2nd ed., 4, 382-407. U.K. Academic Press; https://doi. org/10.1016/B978-0-08-102908-4.00056-4.

Zagorchev, I., P. Tchoumatchenco. 2017. The late Middle Jurassic-Late Jurassic geodynamic revolution on the Balkans. Nat. Confer. Bulg. Geol. Sci., Geosciences 2017, 105-106.

Zagorchev, I., C. Dabovski, T. Nikolov (Eds.). 2009. Geology of Bulgaria. Vol. II, Part 5. Mesozoic Geology. Sofia, Acad. Publ. House "Marin Drinov", 765 p. (in Bulgarian with English summary).

Zagorchev, I., C. Balica, P. Tchoumatchenco, E. Kozhoukharova, I. C. Balintoni, G. Sabau, E. Negulescu. 2018. Jurassic Rhodopes. - Rev. Bulg. Geol. Soc., 79, 3, 79-80. 